\title{
Public value and public services in the post-virus economy
}

TONY KINDER, Ph.D. ${ }^{*}$

JARI STENVALL, Ph.D."

Preliminary communication ${ }^{* *}$

JEL: B40

https://doi.org/10.3326/pse.45.3.2

\footnotetext{
* The authors would like to thank the two independent reviewers for their most useful suggestions and comments.

${ }^{* *}$ Received: November 4, 2020

Accepted: March 24, 2021

Tony KINDER

Tampere University, Faculty of Management, Pinni A Building, Kanslerinrinne 1, 33100 Tampere, Finland e-mail: t.kinder@icloud.com

ORCiD: 0000-0003-2769-3655

Jari STENVALL

Tampere University, Faculty of Management, Pinni A Building, Kanslerinrinne 1, 33100 Tampere, Finland e-mail: jari.stenvall@tuni.fi

ORCiD: 0000-0003-4809-6614
} 
Abstract

This article explores public value and public management through the lens of economic factors - an unusual stance since public management research mostly features the economy as background rather than foreground. Responding to calls for deeper investigations into public value, it argues that public value is not confined to the formal public sector and should also include use-values created and distributed by households, the third-sector and informal associations. Arguing that economic context is paid insufficient attention in public management research, the paper shows how alternative models are possible based on social reproduction, Regulation Theory, and Modern Monetary Theory as an alternative to traditional Keynesianism - favouring a balanced economy above balanced budget.

Keywords: public value, COVID-19, economics, public management

\section{PUBLIC VALUE AFTER THE COVID CRISIS}

In the Great Leveller, Scheidel (2017) notes that crises rupture social affairs, that crises are never neutral, always posing how things will change, who will suffer economically and who will benefit. If COVID proves to be another Great Transformation (Polanyi's 2012 phrase) how will public services be impacted and how, in particular, public value (PV) and public management (PM)? This article explores PV and PM through the lens of economic factors - an unusual stance since PM research mostly features the economy as background rather than as foreground. Responding to Kurz's (2019) important paper arguing that sufficiency should replace efficiency, our article challenges some of his premises and counters Ilyambo and Kaulihowa's (2020) balanced budget argument by counterposing that of the balanced economy.

Our research question - how might the economic change resulting from the virus crisis impact $P V$ and $P M$ - follows four threads, each discussing arguments relevant to current PM research on PV. Each thread connects with Mark Moore's (1995) project of liberating PV from the grip of neoliberal economics.

- Firstly, we explore $P V$ in a post-virus economy contesting the arguments for de-growth proposed in JPS by Kurz (2019) echoing Jackson (2017) and Kallis (2018). We consider the nature of value and how the concept has been and can be used in PM research (Moore, 1995) and then argue that intractable debates around what constitutes PV, for example (Lindgreen et al., 2019), are the result of narrowly defining it as emanating from services funded by the public purse and delivered by public agencies. Our argument is that PV also arises from use-values (UVs) delivered by non-market arrangements, as opposed to exchange values (EVs) delivered using markets and prices. From this viewpoint, UVs and PV include services and goods provided by the formal public sector, households, the third sector (3S) and directly in communities and amongst family and friends. Taking this PV $=U V$ perspective, $P V$ not only has a wider footprint, resurrecting what EP Thompson (1964) referred to as a moral economy but, as will be argued, it is now the dominant form for value distribution, linked closely with policies from the Green New Deal (GND). 
- Our second thread is the post-virus public sector which considers how PV is deployed in PM research. From our UV = PV stance we criticise Vargo, Maglio and Akaka (2008) marketing perspective and Osborne's (2017) idea that there is a logic revolving around the use of co-creation significantly driving PV creation in public services. We follow ideas from normative economics that PV is also concerned with the just use of authority, in this case by addressing first-order policy issues such as full-employment, inequality and a sustainable environment.

- The post-virus economic context of the public sector is our third thread. If neoliberal policies, including austerity are no longer the economic context for public services then what might become the economic context? Both the major orthodox approaches to the economy, we will argue, have proven threatening for public services: neoliberalism hollows-out the public sector and Keynesians too cut back to balance budgets over the economic cycle. We suggest two unorthodox perspectives on the economic context for post-crisis public services: Regulation Theory (Boyer and Shread, 2001) and Modern Monetary Theory (Mitchell, 2020), each seeking to balance the economy rather than balance government budgets. Our approach allows us to reject Baumol's (2012) critique of low productivity in the public sector and instead to support Jansson's (2013) call for an expansion of health, education, and care services (HEC) as a response to social need, automation and demographic change; as Inwin (2019) notes, there is a policy value, which justifies (or not) the accumulation of public debt.

- Post-virus public policy, our fourth strand considers three policy areas in which our blending of economics and PM has something new to say. These are: (a) the GND and associated ten-year transformation of economic activity to create a sustainable natural environment and the central role of PM in planning this change. We then (b) discuss MMT's proposed Job Guarantee (Kelton, 2020) as a way of supporting full-employment in a post-virus world and of supporting Jansson's (2013) HEC expansion, working as a relational partner (Chung's 2016 phrase) the private and 3S. Finally, (c) we consider how PM can align with wider debates addressing social inequality.

The article proceeds by discussing each of these four themes in turn and considers how important public policy goals might be affected by a fresh way of looking at $\mathrm{PV}$ in a post-virus economic setting for public services.

\subsection{WHY VALUE?}

Why discuss value at all, since it is abstract, complicated, not as simple as price and has contested meanings? Mark Moore approaches value from two viewpoints; firstly (1995) from a user perspective he asks managers to find out what would be valuable to do - a demand approach, then (2018) how best to develop a constituency that values what the manager wants or conceives, i.e. supply satisfying demand. In PM research, value is what is demanded, in economics value equates to price. Although Vargo and Lusch (2008) make almost no comment on public services, their service-dominant logic approach views value as being in the eyes 
of the beholder: value is what the customer values. Normann (2002) also views value as subjectively experienced, a concept inherent in Osborne's (2017) public service logic, what is termed in Laitinen, Stenvall and Kinder (2017) migrating values-into-value. Tirronen et al. (2020) show how a public agency can create objective metrics using action learning from service users and (for example, financial, quality and service standards).

Until the second part of the $19^{\text {th }}$ century, most economists followed Smith and Ricardo's explanation of prices as related to the labour-time embedded in the product. Only Marx drew the logical conclusion that labour's share of price under-valued labour's contribution, resulting in exploitation. All agreed that the value of a commodity had two aspects. Use-value (UV) was why consumers wanted the product, the problem the product solved. For Marx (1973: 527) UV is the means of life the material life itself. Exchange-value (EV) was the actual market price. Price did not simply reflect labour hours in the product, since consumers "fetishised" commodities. Later $19^{\text {th }}$ century marginalist economics dropped the UV/EV distinction and with it the labour theory of value, and instead simply equated value with price.

Our argument is that UV remains a useful concept, for understanding public value (PV). Following Elson (1979) we view value as wealth that solves a problem. Public services are UVs distributed by non-market channels and are unpriced. They are subjectively and objectively evaluated by service users and accorded PV. Moore (1995) says that PV is what the public values. Public management literature now abounds with discussion on PV, for example Osborne (2020). Also, economists such as Milanovic (2016) employ UV as a conceptual tool. Our argument joins these two strands together. We argue that PV $=U V$ or wealth solving a problem, created and distributed by non-market means. UV then re-enters discourse as the boundary between market and society, between EV and UV, between value created for the market and value created for non-market distribution.

Precise terminology is always important. Sandel (2009) speaks of social value, meaning individuals' contribution to society; rejecting what he terms economic monism, i.e., reducing everything to price. Confusingly Westall (2009) also uses the term social value, in her case to mean a blended set of social, economic and environmental metrics, a triple bottom-line. Sen (1999) argues that social values and capabilities, being situated in context and culture, are incommensurable between countries. Social value often underpins the idea in social entrepreneurship of a social return on investment (Auerswald, 2007) a view echoed in Knox and Worpole's (2007) ideas for valuing public spaces. There is clearly merit in this blended social value approach, however, we prefer the term UV since it is conventional in economics literature and has a genealogy of meaning in political economy. PV and UV should also not be confused with public goods such as clean air or beaches, which are non-rivalrous and non-excludable, i.e. free for anyone to use.

PM theorists since Moore (1995) have restricted PV to services delivered by formal public agencies; we differ. UV $=$ wealth $=$ PV takes a wider scope and includes 
in PV the UVs created by households, the $3 \mathrm{~S}$, in communities and amongst family and friends. One advantage of our wider footprint for PV is it travels better, since between countries the range of public agency-provided services varies greatly, as Esping-Anderson's (1990) welfare regimes shows. Our view of PV as (problemsolving wealth distributed by non-market channels) is focused on the activities of citizens not of formal structures constituted by the state. Privately produced services-to-the-public are distributed by markets for a price as EVs thus EV = price. As the historian EP Thompson (1963) notes, prior to capitalism, goods and services were typically exchanged as UVs, (this constituted a moral economy founded on mutual obligations); where goods were sold the price was a just price equating to labour time expended in creating the goods. In short, prior to capitalist relations, UVs dominated EVs.

\subsection{USE VALUES DOMINANT?}

Here we present an argument, a line of reasoning that UVs may again be supplanting EVs as the dominant mode of goods and services production and distribution. We leave to a future paper the marshalling of detailed empirical data in support of this proposition. Figure 1 is an indicative example of the prima facie case - taking the example of the UK - of how UVs might be considered dominant.

\subsubsection{GDP A CONTESTED CONCEPT}

Although popularly used, GDP is a contested and ideologically-charged concept. When first proposing GDP calculation Kuznets' (1946) suggestion of measuring welfare not output was dismissed and since then the value of public services features as a negative rather than a positive. Report on French GDP measurement (Wikipedia, 2021) concluded that GDP is a socially-constructed fiction, privileging, as Coyle (2014) notes, private sector activity above that of the public sector. Mazzucato (2018) queries why shareholder value takes precedence over the value of nursing and Christophers (2013) queries why financial intermediation is a positive and care services a negative, and Haldane, Brennan and Madouros (2017) shows that many financial transactions are double-counted. If I hire a gardener the cost is GDP-positive, if I marry her, her work becomes GDP-neutral. More recently, Lazonick and Shin (2020) criticise as legalised looting hedge fund activities, such as share buybacks, that supposedly add to GDP and Birchall (2004) has criticised de-mutualisation of publicly-held organisations, one anomalous result of which is that the same activity magically becomes value-generative in GDP terms.

Other researchers attempt to measure the value of childcare (Suh and Folbre, 2016) and unpaid household activity (Gershuny and Sullivan, 2019). In short, our estimate of GDP composition may be no worse than "official" figures.

Piketty's (2020) point is that even though GDP measurement is ideological, the most important question is its maldistribution in what he terms neo-proprietarian capitalism. Inequitable distribution of GDP, Standing (2016) suggests, arises from monopoly rents on historic intellectual property. Christophers (2018) says the 
privatisation of public assets (10\% of total landmass since 1979 sold) adds inequality and Kallis (2018) draws attention to the environmental costs of profitseeking activities as adding inequalities.

\subsubsection{THE VALUE COMPOSITION OF GDP: UK EXAMPLE}

TABLE 1

Indicative estimates of plausible UK GDP composition

\begin{tabular}{|c|c|c|}
\hline $\begin{array}{l}\text { Traded goods and } \\
\text { services income }\end{array}$ & $\begin{array}{l}\text { Untraded goods and } \\
\text { services value estimates }\end{array}$ & Explanation \\
\hline 2,000 & & $\begin{array}{l}\text { Projected GDP (likely to revise } \\
\text { downwards as a result of virus lockdown) }\end{array}$ \\
\hline \multirow[t]{4}{*}{1,800} & & $\begin{array}{l}\text { Less } 10 \% \text { downward revision, } \\
\text { allowing for virus lockdown }\end{array}$ \\
\hline & -680 & Public sector total spending at $34 \%$ of GDP \\
\hline & -20 & Voluntary sector $1 \%$ GDP contribution \\
\hline & $-1,260$ & $\begin{array}{l}\text { Estimated value of household use-values } \\
\text { (ONS estimates at } 64 \% \text { of GDP) }\end{array}$ \\
\hline 1,800 & $-1,960$ & Totals \\
\hline $90 \%$ & $98 \%$ & Percentage of GDP as EVs and UVs \\
\hline
\end{tabular}

Note: All figures [£] billion and 2020 to 2021.

UK GDP is c£2,000 billion per year (ONS, 2020a), but is likely to contract by perhaps $15 \%$ as a result of the COVID-19 lockdown, with the private sector contributing $90 \%$ of this figure as EVs (Statista, 2020). $£ 2,000 \times 0.85 \times 0.90=£ 1,530$ billion private sector GDP contribution. UVs excluded from GDP include $£ 680$ billion per year public sector spending (ONS, 2020b; Statista, 2020), and a 3S (2016) £200-billion of UVs contributed.

Household UV contribution is contested. Suh and Payne (2019) calculates the market replacement value of childcare work, core housework, household management and travel/shopping time at 25\% of GDP, which Federici (2012) and Gibson-Graham's (2006) method says understates the household contribution of $63 \%$ of GDP. For sake of argument, we take a $43 \%$ mid-way figure of $£ 860$ billion per year, noting that already many women are paid for housework, however, as Wolf (2017) points out, not their own housework, but that of richer women successful in market-based relationships. Drawing attention to women acting as carers for the elderly, elements of what Federici (2012) calls a triple-shift go financially unrewarded; a situation likely to increase as Ermisch's (1990) predicted Fewer Babies, Longer Lives proves prescient. Federici (2012) and Hockschild (2013) call for more state support to household activity, including nursery care and family financial benefits nearer to a wage. Ironmonger (2004) and others identify a wide range of emotional care UVs not included in these figures, to which might also be added: (a) replacement capital equipment or household transport UVs, Parmar's (2017) research shows, also adds significant non-GDP UVs; (b) care of 8-million elders (Wincer, 2020); (c) co-created UVs benefiting the private sector services; and (d) many UVs created and 
distributed by religious and community groups and amongst family and friends. We make no claim to a rigorous computation, simply that there is a plausible case that UVs are now the dominant means of value production and distribution in the UK economy: a conclusion, which if plausible, has important implications for PM. Bridgeman et al. (2012) surveys these issues and agrees with Coyle (2014) that GDP is a fiction. For the purpose of this article we are exercising a fiction that privileges UVs leaving precise computation and other countries to further research.

There is no universally-applied method for calculating PV by Supreme Audit Institutions, Cordery and Hay (2019) note, suggesting that it is reasonable, for the sake of argument in the rest of this paper to assume that UVs are now the dominant form of value production and distribution in the UK and perhaps in other developed economic contexts for public services.

\subsection{PUBLIC MANAGEMENT RESEARCH AND PUBIC VALUE:}

TO WHAT QUESTIONS IS PUBLIC VALUE THE ANSWER?

We have argued that the post-virus world can be a point of transformation for public services and that already a plausible case can be made that UVs and PV are the dominant form of value creation and distribution. This section relates these ideas to the body of PM research on PV. Table 2 summarises our analysis of existing literature, which is enormous (some 650 articles, in ten years). Often as Colon and Guerin-Schneider (2015) note, PV criticises new public management (NPM). Van der Wall et al. (2015) identifies 550 different PV concepts.

Our classification of PV research reflects our view that UV $=$ PV. Gooberman and Hauptmeier (2019) use a three-way classification of PV debates: (a) Bozeman's (2002) social outcomes, (b) Moore's (1995) Public Managers-created value, and (c) Meynhardt's $(2009,2019)$ individual psychological values. As in the rest of the book of Lindgreen et al. (2019) they make no mention of PV co-creation or Vargo and Lusch's (2008) service-dominant logic and confine their view of PV to that created by the publicly-funded public sector. Jorgsen and Bozeman's (2007) classification of PV is also restricted to the publicly-funded public sector. It confuses value and values: for example, under the heading "Public Value is not Governmental" they go onto speak of the values held by non-Government agents. They make no mention of co-creation or of value created by the public outside for the formal public sector. The three thematic approaches suggested by Bozeman and Johnson (2014: 62), i.e., policy application, normative criteria and improvement, usefully structures the literature from the policy perspective. According to Meynhardt (2019) PV research follows five strands: usefulness of operations, profitability/cost, ethics, political acceptability and user experiences.

Our trawl of literature, which is not systematic, from a PV-creation and economy stance resulted in the three major perspectives shown in table 2: marketing, cocreation and engagement and PV-management, which we break down into thirteen sub-themes. 
To summarise our findings, all the literature allots a narrow footprint to PV as arising from formal public agencies and does not, as we argue it should, include UV production and distribution. The literature relates PV passively to economic context whereas we will show PV can spur unorthodox new thinking around the PV/ economy interrelationship.

\subsubsection{VALUES-TO-VALUE}

For Moore (2005), Benington (2009) and Benington and Moore (2011) PV is a cost-benefit justification of publicly funded services; managers are responsible for improving PV. As the discussion above reveals, our concept of PV has the wider scope of UV services-to-the-public, including public services, and non-market household, voluntary organisation and caring activities: unpaid and paid. Our notion of value also differs from Moore and Benington for whom value is commensurate with private sector offers - it is financially comparative. Our starting point is that UVs constitute value, often only notionally comparable with market prices, since they are produced and distributed using non-market modes: we analyse PV from a different epistemological starting point.

\section{TABLE 2}

Key themes in PM research relating to PV

PM PV themes Sub-themes Authors

(1) Values to value: the marketing perspective

\begin{tabular}{|c|c|c|}
\hline \multirow{3}{*}{$\begin{array}{l}\text { Subjective } \\
\text { user-satisfaction } \\
\text { measurement }\end{array}$} & Value alternative to NPM & $\begin{array}{l}\text { Moore (2005); } \\
\text { Benington (2009), }\end{array}$ \\
\hline & $\begin{array}{l}\text { Normative, metaphoric } \\
\text { alternative to price and } \\
\text { efficiency (NPM) }\end{array}$ & $\begin{array}{l}\text { Vargo and Lusch (2008) } \\
\text { paradigm switch } \\
\text { (private sector) }\end{array}$ \\
\hline & $\begin{array}{l}\text { Subjective user-satisfaction, } \\
\text { metrics and PV } \\
\text { management }\end{array}$ & $\begin{array}{l}\text { Stoker (2006); } \\
\text { Behn (2001); } \\
\text { Mulgan (2002) }\end{array}$ \\
\hline \multirow{2}{*}{ Ranking values } & \multirow{2}{*}{$\begin{array}{l}\text { Value situated: no } \\
\text { consensus across time } \\
\text { and space }\end{array}$} & $\begin{array}{l}\text { Rutgers (2008); Kahneman } \\
\text { and Tversky (1979) }\end{array}$ \\
\hline & & $\begin{array}{l}\text { Sandel (2009) on justice; } \\
\text { Milanovic (2016) needs/wants }\end{array}$ \\
\hline \multirow[b]{2}{*}{$\begin{array}{l}\text { Subjective and objective } \\
\text { user-satisfaction } \\
\text { measurement }\end{array}$} & \multirow{2}{*}{$\begin{array}{l}\text { PV solves users' problems } \\
\text { using UVs: crossing all } \\
\text { governances not confined } \\
\text { to private or private sector; } \\
\text { negotiated in each situation }\end{array}$} & Laitinen (2017) \\
\hline & & $\begin{array}{l}\text { Cordery and Hay (2019); } \\
\text { Tirronen et al. (2020) }\end{array}$ \\
\hline \multicolumn{3}{|c|}{ (2) Cocreation: the engagement perspective } \\
\hline \multirow{2}{*}{$\begin{array}{l}\text { User-led innovation } \\
\text { frame }\end{array}$} & \multirow{2}{*}{$\begin{array}{l}\text { Social shaping } \\
\text { of technology }\end{array}$} & Von Hippel (1988) \\
\hline & & Mackenzie and Wajcman (1985) \\
\hline Production frame & $\begin{array}{l}\text { PV a better frame for } \\
\text { problem-solving than } \\
\text { cocreation; collective value }\end{array}$ & $\begin{array}{l}\text { Liebenstein (1966); } \\
\text { Ostrom (1996); } \\
\text { Connolly and Wall (2016) }\end{array}$ \\
\hline New public governances & $\begin{array}{l}\text { Public Service Dominant } \\
\text { Logic }\end{array}$ & Osborne (2017) \\
\hline
\end{tabular}




\begin{tabular}{|c|c|c|}
\hline \multicolumn{3}{|c|}{ (3) Public value management: the management perspective } \\
\hline PVM paradigm & $\begin{array}{l}\text { Manager at the centre } \\
\text { driving change towards } \\
\text { user needs }\end{array}$ & $\begin{array}{l}\text { Normann (2002); } \\
\text { Stoker (2006); } \\
\text { Grönroos (2013) }\end{array}$ \\
\hline $\begin{array}{l}\text { Value-creating not only } \\
\text { value-distributing state }\end{array}$ & $\begin{array}{l}\text { Not bureaucratic, } \\
\text { entrepreneurial }\end{array}$ & $\begin{array}{l}\text { Mazzucato (2013); } \\
\text { Inwin (2019) }\end{array}$ \\
\hline $\begin{array}{l}\text { Urban regime/change } \\
\text { coalition }\end{array}$ & Localist new governances & Bardach (1998) \\
\hline $\begin{array}{l}\text { Localised interactions: } \\
\text { value flow patterns create } \\
\text { "soft" structures }\end{array}$ & Governance-as-legitimacy & $\begin{array}{l}\text { Laclau (1990); } \\
\text { Kinder et al. (2020) }\end{array}$ \\
\hline $\begin{array}{l}\text { "e" with everything: } \\
\text { technology-led change }\end{array}$ & $\begin{array}{l}\text { Technology-led change, } \\
\text { e.g. AI }\end{array}$ & $\begin{array}{l}\text { Cordella and Bonina 2012; } \\
\text { Goldin and Katz's (2008); } \\
\text { Kinder (2020a) }\end{array}$ \\
\hline
\end{tabular}

Source: Authors.

\subsubsection{VALUES-TO-VALUE AS A NORMATIVE, METAPHORIC ALTERNATIVE TO NEW PUBLIC MANAGEMENT}

Migrating public values into PV, as Roberts (1995) notes, is a general orientation, not associated with specific management techniques or metrics, whereas Stoker's (2006) public value management (PVM) makes the PV perspective managerialist. For example, Vargo and Lusch's (2008) marketing framework of service-dominant logic, which makes little mention of public services, invokes customer-value, yet lacks the detailed, pragmatic toolkit PVM offers. Ostrom (1990) anticipates that polycentricity will embed public values, again at a generic level, in her case as collective goods. She uses the term PV in a metaphoric sense, applying it to market and non-market services. Whiteside (2011) too views PV metaphorically. The managers of Denhardt and Denhardt (2000) are urged to "serve" by enhancing PV, although there is no prescripton of how they are to recognise it or measure achievement. As Aligica and Tarko (2013: 728) note, there is a body of PM literature in which [t] he semantic ambiguity surrounding the concept of values is notorious: values as intuitions, values as cultural ideals, values as beliefs, values as generalised attributes, values as transcendental, values as naturalised. We consider PV a practical problem-solving approach, measurable using objective and subjective criteria. Unlike Stoker we do not limit PV to the formal public sector or to evaluation by Public Managers.

\subsubsection{VALUES-TO-VALUE: SUBJECTIVE USER-SATISFACTION MEASUREMENT}

Since services are characterised by being experienced subjectively by users, the value of services for researchers such as Vargo and Lusch (2008) and Mulgan (2007) is relative to the individual user: a marketing satisfaction perspective. This leads Rhodes and Wanna (2007) to criticise the substitution of satisfaction data for problem-solving policy-making, Cordery and Hay's (2019) just use of authority. All public choice approaches to value, Aligica and Tarko (2013) argue, are light on theory and stronger on responsiveness to public expressions of subjective satisfaction. Our perspective is that $\mathrm{PV}$ cannot be reduced to psychological impressions - the starting 
point of UVs is solving problems not public opinion. For example, opposition to replacing residential care by independent living (Kinder, 2003) scores low on psychological satisfaction but high on problem-solving.

\subsubsection{VALUE-TO-VALUE: RANKING VALUES}

Ranking of values is good sport for philosophers: for Sandel (2009), justice trumps equality, for Milanovic (2016), needs rank above wants. Bozeman (2007) argues values can act as standards against which PV is judged and Bozeman and Sarewitz (2011) suggest ranking values to evaluate research programmes. Since values only alter slowly, Omurgonulsen and Oktem (2009) argue, they can be used to rank rights, obligations, and principles of government. Value ranking is central to Kahneman and Tversky's (1979) decision-modelling and Mitchell and Carson's (1989) idea of evaluating public services using satisfaction surveys. Even when values are not consensually accepted, Jørgensen's (2009) Danish study argues that making value transparency helps public debate. Since value ranking varies between context and culture (Rutgers, 2008), no universally accepted ranking of values is likely to emerge; instead a situated valuing of wealth that resolves situated problems may help identify PV.

\subsubsection{VALUES-TO-VALUE: SUBJECTIVE AND OBJECTIVE USER-SATISFACTION MEASUREMENT}

For Benington (2011), PV embeds desirable values and is evaluated using combinations of subjective and objective metrics, (citing inputs, processes and outcomes), to establish how valued public services are and how valuable they are in solving problems. As Bryson, Crosby and Stone (2014) point out such a multidimensional approach can give more sophisticated information than price signalling from markets: they point to feedback giving innovation ideas and the build-up of trust. The Tirronen et al. (2020) application of this approach to user wellbeing in the integrated service hubs for elderly citizens living independently is an example. UVs, by definition, solve problems and therefore to some degree embody citizens' values; the careful identification of objective and subjective values may enable providers to amplify positive PVs and reduce value-negatives.

\subsubsection{CO-CREATION AND PUBLIC SERVICE LOGIC}

Customer value is the founding principle of marketing (Kotler, 1984). For services, another example is Vargo and Lusch's (2008) value-in-use that results from customer involvement in product design and/or delivery: customers co-create services. Their idea is to shift attention from production to utilization, from product to process, from transaction to relationship (2008: 151), suggesting a paradigm shift from a goods-dominant to a service-dominant logic in which value is benefit (Vargo and Lusch, 2014: 57). Their focus is marketing private sector goods: they make almost no reference to public services or PV. Osborne's (2017) public service dominant logic combines SDL with new public governances and a serviceuser orientation that frames public services through the lens of co-creation. This aligns with, though differs from, the views of Grönroos (2007) and Normann 
(2002), who focus on management of service systems, which in turn they differentiate from public choice theory (Ostrom, 1996; Wensley and Moor, 2011). Our PV perspective allows a wider footprint for UV creation and does not regard cocreation as essential to its creation.

\subsubsection{CO-CREATION PRODUCTION}

For "left" communitarians co-creation is an exercise in shared responsibility and user involvement (Giddens, 1991; Alford, 2011); while "right" communitarians view co-creation as a means of reducing paid-for public provision (Brookshie and Cursey, 1987). Kelly, Mulgan and Muers (2002) insist PV means citizens must be willing to give something up in return for it - in the case of co-creation, their unpaid labour. Try and Radnor (2007) and Meynhardt (2009) insist that co-created PV improves service quality, leaving unanswered who pays for the cost of quality. In Leibenstein's (1966) terms, co-created PV reallocates cost and responsibility from public agency to citizen. Co-creation, as Laitinen, Stenvall and Kinder (2017) point out operates at different levels, varies between contextual trust, and has a multiplicity of meanings: user-led or use-influenced services.

\subsubsection{PUBLIC VALUE MANAGEMENT}

Stoker's (2006) PVM allocates pivotal agency to the Public Manager who filters co-creation ideas and opportunities; an idea close to Grönroos and Ojasalo (2004) and Grönroos and Voima (2013) notion that Public Managers listen, learn, and innovate, and also close to the primacy of leadership in Hartley et al. (2014). Crouch's (2011) PVM emphasises hybrid governance, echoing Ostrom's (1996) idea that polycentricity creates innovation. PVM seeks opportunities to enhance efficiency and effectiveness in network and hybrid governance, a localist perspective, which though Manager-centred may offer democratic renewal (Horner and Hutton, 2011) and localised governance-as-legitimacy (Kinder et al., 2020). Connolly and Wall (2016) take the wider view of value-capture. The PVM perspective links with Mazzucato's (2013) arguments on the entrepreneurial (value-adding, rather than value-distributive) state and Janeway's (2018) view that state agencies are important conduits of innovation. Our view of PV is wider than Stoker's (2006: 46), which restricts PV to the formal public sector.

\subsection{9 e-WITH EVERYTHING}

A final cross-cutting strand of PM research relevant to PV is closing the gap between science and technology (S\&T), i.e. invention and innovation: increasing the pace of technology-led innovation in areas such as artificial intelligence (Kinder et al., 2020) and big data analytics (Kuoppakangas et al., 2019). Long-term e-service examples in HEC abound: healthcare pharmaceuticals, IT in education and alert, alarm and assistive technologies in care services. Technological innovation is accompanied by socio-ethical issues influenced by negotiations around the pace and direction of change, and the distribution of (dis)-benefits (Kinder, 2012). Too often "e" with everything, from digitalisation to machine learning is viewed as a panacea for problems in services to the public (Cordella and Bonina, 2012). Examples of AI abuse in 
O’Neil (2016), Brindle (2018) and Eubanks (2017) illustrate this point. Invariably the smartness is not in the technical networks and instead in how people adapt to new opportunities - Goldin and Katz's (2008) race between education and technology. S\&T, then, can create and destroy PV.

To summarise, whereas Moore (1995) and most PV researchers call for market distributed value to feature more $\mathrm{PV}$, our emphasis is on $\mathrm{PV}$ as UVs produced and distribution by non-market channels. Reconceptualising PV to include UVs created by households, the $3 \mathrm{~S}$ and community associations in addition to the formal public sector opens new vistas in research on value, especially for PM research. Viewing PV as problem-solving, draws attention away from psychological satisfaction (Meynhardt, 2009; 2019) or deduced values (Rutger, 2020) and Stoker's (2006) manager-centricity. PM research on co-creation fails to address Leibenstein's (1966) criticism that co-creation simply shift costs. Sheikh and Yousafzai (2020) come close to our perspective; however, they view PV as mediated through the market, unlike our non-market view of $\mathrm{PV}$ production and distribution. Though Moore's (1995; Moore and Khargram, 2004; Moore, 2018) project of disentangling PV from neoliberalism's obsession with financial performance remains relevant, our $\mathrm{UV}=\mathrm{PV}$ adopts the wider footprint for PV creation and non-market distribution. Following Moore's project, we now turn to unorthodox economic perspectives offering alternative approaches, remaining convinced that the lens of economics helps reveal the nature of PV in a post-virus world.

\subsection{PUBLIC VALUE IN A POST-VIRUS CHANGING ECONOMY?}

To take stock. Discussing PV in a post-virus world we have argued that, since UVs may now be the dominant form of value production and distribution, a transformation may be occurring in which neo-liberal market mediation ceases to dictate value relations and instead a new balance is negotiated between shareholder value and social values. We suggest that PV is best conceptualised more widely than through public agency-provided services, to include UVs created in households and the 3S. Our UV perspective includes UVs in PV: wealth that solves a problem for citizens. So far, our discussion has placed the public sector within an economic environment in which markets mediate value relations. But what if the post-virus economy alters? An economy supportive of public services and PV would seek arrangements other than neoliberal tax cuts and austerity that balanced state budgets rather than the economy. Similarly, Keynesian demand management, which balances budgets, over the economic cycle, has since Prime Minister Callaghan in 1976, and Presidents Mitterrand in 1983 and Clinton in 1996 reduced state spending. Perhaps the post-virus economy will adopt perspectives more supportive of the public sector and PV? Here we consider unorthodox economic perspectives Regulation Theory and Modern Monetary Theory - showing how each favours $\mathrm{PV}$ and how the two can synthesise.

Regulation Theory (Aglietta, 1979; Boyer and Shread, 2001) envisages the economy in two parts: a regime of accumulation and a mode of regulation, arguing that 
when these parts are aligned the economy grows healthily (Streeck, 1992; Warde, 1994). Both the regime and mode of regulation organise people, markets, finance, knowledge, and the state in ways that match production and consumption. This model is similar to the development state (Johnson, 1982; Woo-Cummings, 1999) first witnessed in Japan, later in the "Asian Tigers" and now in (with quite different ideological content) in Socialism with Chinese Characteristics. Social reproduction in these economies features modes of regulation (consumption patterns, family, and education) aligned to the needs of the accumulation regime. Regulation is a major body of theory, the subtleties of which cannot be presented here. In table 3 and figure 1, the regulation approach is represented in (5) and (6), with (10) and (11) showing the mutually supportive relationship between the regime of accumulation and the mode of regulation. Note that environmental sustainability (12) is an essential ingredient of this perspective (we discuss the Green New Deal below), which is a meta-level view of the economy in which public services play an essential part. The model recognises that without PVs in HEC and public services supportive of production and consumption, the economy could not function - value produced in families is centrally important. The unorthodox Regulation approach is one example of unorthodox alternatives to neoliberalism and Keynesianism that might guide the post-virus economy, placing PV as a central variable.

A second unorthodox alternative to neoliberalism and Keynesianism is Modern Monetary Theory (MMT; Mitchell, 2020; Kelton, 2020). Its central idea is that an economy can adopt the goal of full-employment, including a Jobs Guarantee, financing this if necessary, by a permanent deficit, available to countries that issue their own fiat currency (not convertible to precious metal). MMT's insight is that governments are unlike households; they do not save-to-spend; instead, governments spend and then if necessary, tax and borrow, provided they are currency issuers. By spending (on Job Guarantee or HEC employment or boosting aggregate demand), MMT raises overall output by avoiding the waste of unemployment, which lowers output. Where international trade and the private sector are in surplus (paying taxes and funding Government borrowing), Government have no need to deficit-finance. Where the private sector is in deficit, Government spending boosts economic activity. Since a currency-issuing state can never go bankrupt, the Government is able to deficit-finance in the long-term, balancing the economy, as Japan has done for thirty-years, and not the Government budget. Unlike Keynesians, MMT has no need to balance budgets by cutting spending over the period of an economic cycle. At the centre of table 3 are three sectors of the economy: (1) public, (2) private, and (3) international trade. These interrelate (8) and (9) and where private and international trade are insufficient to provide full employment (7) the state deficit-finances. It does this not by borrowing and taxing, but simply by the Treasury spending via the Central Bank. The state uses targeted fiscal policy (taxes) to manage inflation (if the private sector overheats) and to pursue progressive taxation, perhaps of the sort envisaged by Piketty (2013, 2020). Note that like Regulation Theory, MMT at (12) too pursues full employment within the confines of a sustainable environment by implementing the Green 
New Deal, i.e. state-led and enabled "greening" of the economy as a new sociotechnical growth paradigm. MMT views the economy as flows and stocks of income and capital. The basic model is: Gross National Product is made up of consumption (C) plus investment (I), plus government spending $(\mathrm{G})$, plus the balance of trade (X-exports less $\mathrm{M}$-imports), plus net receipts from financial investment internationally (FNI). GNP balance at full employment means all labour resources are being used; there is no wasteful unemployment.

$$
\mathrm{GNP}=\mathrm{C}+\mathrm{I}+\mathrm{G}+(\mathrm{X}-\mathrm{M})+\mathrm{FNI}
$$

Regulation Theory and MMT literature do not themselves envisage a synthesis, which is presented here to illustrate those alternatives to neoliberalist and Keynesian economic management are possible in a post-virus world. Such a synthesis would view public services as central to the well-functioning of the economy and society and not parasitical; and able to support expanded HEC employment and maximise PV, for example using a Jobs Guarantee to validate and support UV creation in households and the $3 \mathrm{~S}$ (CNBC, 2019).

There are widespread criticisms of MMT as a magic money tree. Epstein (2019) argues that only the US dollar is sufficiently strong to trade with a permanent deficit. His Keynesian view, that deficits need repaying over the economic cycle is echoed by Paul Krugman (2020a), who notes that persistent low-interest borrowing is unlikely. Monetarists reject MMT arguing that deficits cause inflation and inflation causes unemployment (the Phillips curve trade-off): they instead favour austerity and a balanced budget. Mitchell (2020) rejects these arguments and debate continues.

\section{TABLE 3}

Factors constituting a simplified economy

Factor and function

1

Government provides public services and manages economy

3

International trade sector balance of trade and payments

\section{Activity and relationships}

Manages state spending level and deficit; sets interest rates, exchange rate band and employment target, aligns Treasury and Central Bank: manages aggregate-demand; spends before taxing and borrowing. Pays taxes and interest to itself.

Invests, employs and sells to suit profitmaking at times leaving deficit state can fill be creating aggregate-demand that stimulates investment and economic activity. Pays taxes to Government, purchases Treasury debt. Overall international trade balance (goods and services) creating surplus or deficit of foreign currency; inward and outward capital investment Quality of nature is/should be a constraint on economic activity and positive externalities; state control of negative externalities, such as carbon emissions, degrading and abuse 
Factor and function

Activity and relationships

Production, supply, 5-factors, e.g. different

5 Regime of accumulation: production of goods and services

Mode of regulation: consumption

6 of goods and services, provision of labour force and carers

7 Balance economy not budget

State regulates markets, sets legal

8 and fiscal regime, gathers taxes, manages aggregate-demand

9

Trades, goods, services and capital, including migration

10

Alignment of mode regime with mode

11 Alignment of mode with regime

12 Mode and regime and nature
Fordist to post-Fordist and neoliberal; drivers: accumulation + dominant value relationships (EV or mixed and UV)

Consumption, demand, market regulation, SCM internationally, ways we buy life-as-lived S(TAB) not TAB(S) BUT activity might be non-market; inflation danger (Mattick) state spend $>$ productivity

Balance in economy; if growth by private sector stalls, need aggregate-D boost by public

State vies with MNCs to control international trade: tariffs, regulations, OFDI and IFDI; currency exposure; fiat currency Overall economy alignment: supply/demand; production/consumption: 5-factors in either side; complexity economics

Misalignment $=$ crisis (accumulation opportunities, including internationally); also, who pays price of crisis?

Nature; Burkett; > constraint, wellbeing and QWL

Source: Authors.

\section{Figure 1}

Simplified economy model showing regulation theory alignment between regime of accumulation and mode of regulation

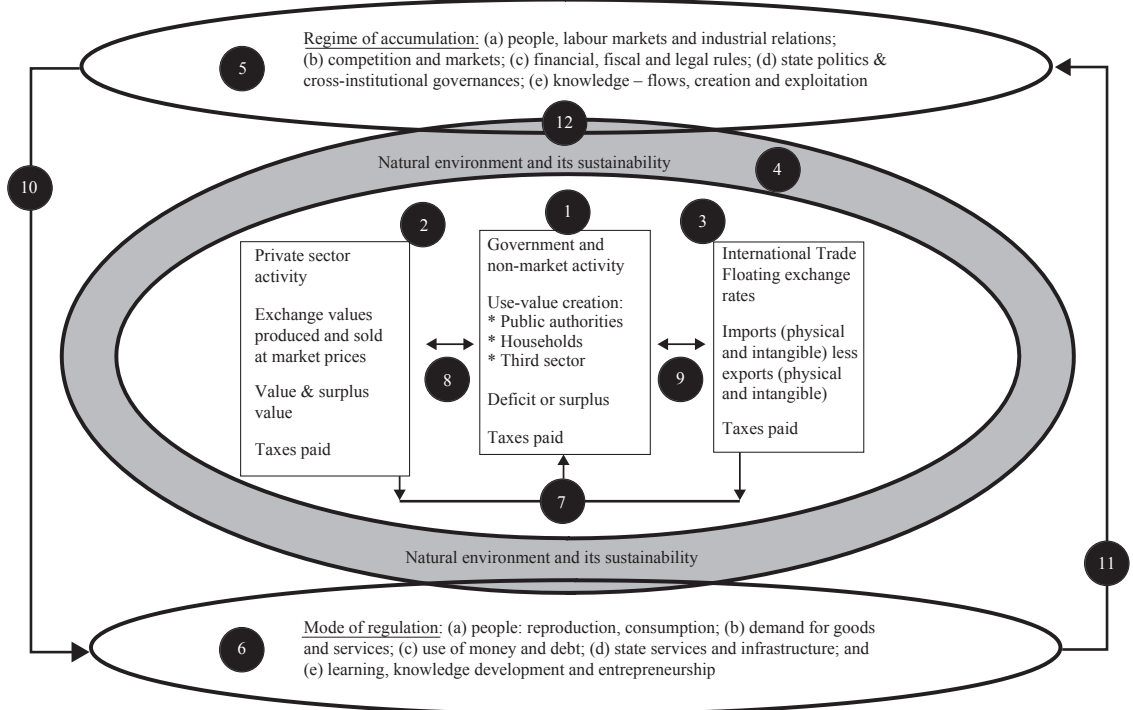

Source: Authors. 
We have shown that unorthodox alternatives to neoliberal and Keynesian approaches to economic management exist and some, such as Regulation Theory and MMT provide much more favourable contexts for public services. We now turn to how in a post-virus world these approaches could reshape public policies and services.

\section{POST-VIRUS PUBLIC VALUE AND PUBLIC POLICIES}

Having discussed PV in a post-virus world, a post-virus public sector and the postvirus economic context we now have a set of conceptual instruments in place to discuss post-virus PV from the viewpoint of policy value (Inwin, 2019) in four high-level policy areas: full employment and the job guarantee; GND; HEC, and wealth taxes.

\subsection{POST-VIRUS FULL EMPLOYMENT}

Unemployment wastes human life resulting in socio-psychological disorders and leaves unmet PVs much in demand, lowering output. Current issues include precariat fragile low-waged jobs (Standing, 2016), low incomes (Avent, 2017) and dire predictions of technological unemployment (McAfee and Brynjolfsson, 2014) weakening aggregate demand. Jansson (2013) proposes meeting PV demands by expanding HEC employment and training, while acknowledging opposition from neoliberals who campaign for a smaller state and lower taxes (Winters, 2011; Mayer, 2016) and recently for competitive national economies, as opposed to globalisation (Slobodian, 2018). Amongst Keynesians, Galbraith expresses a culture of contentment fear against raising taxes to fund state spending. In terms of the model in table 1, HEC expansion is necessary, since only an educated and healthy population can support continued science-based innovations and an expanding service sector.

One proposal is universal basic income (UBI) (Sen, 1985; Haagh, 2019; Van Parijs and Vanderborght, 2020), the cost of which varies given diverse current levels of welfare support. UBI claims to offer social inclusion/dignity, labour mobility, life-long learning, and increased participation in $3 \mathrm{~S} \mathrm{PV}$ creation, associating UBI with universal basic services (UBS; Coote and Percy, 2020). UBI is paid to the individual and is subject to the criticism of subsidising low wages. Alternative, MMT's proposed Job Guarantee can include an expansion of HEC employment and training implemented by local government; it includes training in sectors likely to result in future private sector employment (Tcherneva, 2012), with the wage at a living wage level, effectively pulling minimum wages upwards (Paul, Darity and Hamilton, 2018). MMT argues that full employment maximises an economy's output by eradicating unemployment, with a multiplier-effect of aggregate demand for private sector goods (Mitchell and Fazi, 2017).

In summary, an alternative narrative to right-populism might begin with a (MMT) jobs guarantee based on HEC expansion and wave of "green" socio-technical paradigm growth and trade. Such a scenario implies a new social mode of 
regulation based on reduced inequality and exclusion, providing dignity and wellbeing especially for otherwise unemployed citizens. It also adds PV, supporting new ways of creating (and computing) value. Our point is that these arguments should be acknowledged and are best framed from a perspective of UVs now dominating value production and distribution.

\subsection{WEALTH TAX}

A Regulation economy invests heavily in people and knowledge, embracing technological advances requiring knowledge workers. The tax-take from such an economy may result (table 1) in inflation, overheating the private sector. MMT theory sequences spend, then tax and borrow in contrast to the Keynesian tax and borrow, then spend. Instead of revenue-raising, MMT envisages targeted taxation to control aggregate demand and achieve more equal wealth distribution. This aims for a lower Gini index of inequality that Atkinson (2015) correlates with higher economic performance. Post-virus austerity programmes, as advocated by neo-liberal economists, including developing economies (Ilyambo and Kaulihowa, 2020) would act as a negative multiplier and lead to depression and falling asset prices.

Piketty (2013), noting the historically high growth rates by western economies 1945-73 at a time when the top rate of income tax averaged $90 \%$, famously argues that since $1973 \mathrm{r}>\mathrm{g}$ i.e. returns to capital have exceeded economic growth. Like Bauman (2013), Piketty (2020) rejects trickle-down wealth creation arguments incentivising billionaires to invest and instead proposes an annual 5\% wealth tax on assets above $€ 2$-billion, the proceed of which are to go (in our terms) to UVs. These arguments gain support from non-MMT economists such as Milanovic (2016), Eubanks (2017), Crouch (2020) and Paul Krugman (2020). Piketty's colleague Zucman (2015) argues that the EU Tax Directive is failing, because of EU-allowed tax shelters. For example, the up to \$2.3-trillion held in Switzerland, mostly owned by Europeans exposed by Shaxson (2016) in Treasure Islands. Delong (2017) suggests imitating Norway's public asset register as a first step.

Whereas US legislators periodically cut taxes and then pursue balanced budgets by cutting spending on public services, MMT proposes spending to expand services followed by fiscal policies to stem inflation and equalise wealth distribution. Maximising PV instead of shareholder value is an argument of high resonance in the post-virus world in which the results of neoliberalism - exploitative value chains, rising inequality, and social exclusion - are increasingly being challenged. So too, is impact of neoliberalism on our natural heritage and living conditions.

\subsection{THE GREEN NEW DEAL}

Absolute de-coupling resource use and economic activity now appears essential if global warming and environmental degrading are to be avoided, according to Monbiot (2015). The limits to growth Hirsch (1976) and Schumaker (1985) predicted have been reached. Leaving resource exploitation to individual companies is no longer an option since shareholder value maximisation conflicts with 
environmental PV costs. De-coupling would entail a fundamental paradigm shift in how environmental sustainability issues are approached. Re-focusing activity on UVs is central to important debates on environmental issues. How much can the natural environment be utilised, while maintaining its sustainability? Also, natural objects only gain value (UV or EV) when worked upon by labour, can the idea of natural capital as a UV be measured and balanced against private capital accumulation which often deplete natural capital?

Mitchell (2020) outline a GND plan to create a non-carbon, sustainable economy over perhaps ten-years, using deficit-funding to radically alter the economy: private, public and international sectors - while at the same time addressing inequality using the Job Guarantee and progressive taxation. This aligns with the urgency advocated by Greta Thunberg (2019) and the Stern Report (2006), Klein (2019) and Kolbert's (2011) Anthropocene extinction warning.

Much of the capital and labour resources a GND needs are in the private sector, which would be mobilised behind the GND plan using Government planning and funding. In some cases, the plan might involve state ownership, though leveraging private investment is preferred. Problem areas, such as big oil's assets and infrastructure may require state ownership of old assets, while diversifying. GND promoters draw parallels with arms conversion after 1945. Reducing military spending and arms manufacturing is part of the GND, shifting resources from destructive to productive use, for example, in HEC sectors. The GND envisages close partnership with developing countries as food and raw material supply chains alter. GND means major retraining of human capital. In summary, the GND envisages a massive deficit-funded transformation of the economy using public-private partnering; a fundamental refocusing of market incentives and international relations.

Raey (2009) offers a slower, market-led alternative to MMT's GND. Others favour the more radical policy of de-growth (Kallis, 2018; Kurz, 2019) involving static or falling living standards. Dietz and O'Neill (2013) challenge the idea that economic innovation is always beneficial and calls for a steady-state economy, abandoning carbon-based industries such as airlines and oil.

Mitchell and Fazi (2017) note that an effective GDN necessitates a significant increase in planning. They proceed without a critical analysis of post-war nationalisation, French state planning or the 1930s theoretical debate on planning involving Von Mises and later Hayek against Hilferding, Lange and Dobbs. As Cottrell and Cockshott (1993) note, major companies now employ sophisticated planning techniques, often using AI, without the economic meltdown Von Mises et al. predict from abandoning market signalling (Barbrook, 2017). Social acceptance of GND planning needs to closely engage citizens, involve companies with expertise, learn lessons from the early work of Kantorovich (1939), Beer's projects in China (Beer, 1979; Medina, 2011) and from the Asian development state experiences (Chang, 1994). In short, a radical GND can align with MMT proposals for a Job Guarantee with state-led planning. 
How revelatory for thinking about PV in the post-virus world is the marriage of PM and economics; in particular, the notion that UVs may be the predominant manner of value distribution?

According to the WHO (2020), there will be no post-virus economy in the sense that viruses are an integral part of economic activity as currently constituted: we have suffered 70 virus epidemics in the last 20-years and 300 new pathogens threaten zoonotic transmission in years to come. Discussing the bio-pharmaceutical industry, Pisano (2011) makes the point big pharma categorises many diseases as difficult to research, by which it means unprofitable to research. Although finding vaccines is a social (UV) priority, as the Economist (25 June 2020) notes, it has not been a priority of for-profit pharmaceutical companies, despite them benefitting from publicly-funded basic research. Are we to rely on the decisions of billionaire philanthropists for such research when their manner of wealth accumulation has been ethically questionable, as Mayer (2016) and Wahhab (2016) argue? This issue vividly illustrates the central issue of PV: the priority given to societal UVs relative to the economy's accumulation and profit driver? To embed ideas such as these, PM and social policy theorists might begin by accepting that "economy" is not background with PM as a passive recipient; instead, for PM to enlarge PV, PM research needs to give more foreground attention to economics, heeding where the market/society boundary is drawn.

Mark Moore's project has successfully placed PV on an agenda previously dominated by neoliberal economics, which mediates public service activities via the market. Neoliberal hegemonic market-dominance continues to reinvent itself as the dominant discourse, framing PV decisions around metaphors such as the economy is like a household; can society afford it; we can't pass on intergenerational debt, and the private sector has to make money before the public sector can spend it. Since Keynesianism degenerates into public spending cuts, if the economy is to serve society, instead of society being subjugated to the economy, PM research needs a clearer vision of PV than we find in some of the literature discussed above. PM needs to challenge the economic environment, highlighting alternatives to neoliberalism, such as Regulation Theory and MMT, Jansson's ideas for HEC expansion, and the notion that PV can be created outside the formal public sector and distributed as UVs using non-market channels. The balance between for-profit and UV activity will vary between countries. For example, some states will accept capitalism without capital (Haskel and Westlake, 2018) exploiting the public infrastructure; other countries, such as China are unlikely to deviate from their successful development state model (Lewin et al., 2016). Our point is that there are alternatives to the neoliberal model.

Like Piketty's (2020) radical proposals on progressive taxation, the policy agendas of Regulation Theory and MMT will only be implemented if progressive PM policy-makers achieve power; an unlikely prospect for countries such as the US 
and UK and less so for federations such as the EU with the Central Bank constituted with neoliberal goals. For complexity theorists, such as Arthur (2015) the hope is that ecosystems will allow bottom-up change drivers to take hold. Cordery and Hay (2019) point out that bottom-up change, enjoying the legitimacy of wide acceptance may deliver more radical change than top-down disruptive policies.

There is no inevitability of progress and especially so in the post-virus world since economies will emerge burdened with debt, advised by neoliberals and Keynesians to pay down debt stock and reduce debt flows (current spending). Instead of HEC being expanded, will further areas of public activity be privatised, in place of the new governances targeting new effective models of public services hoped for Osborne et al. (1996, 2005, 2017)?

Yet, oligarchic power (Winters, 2011) and rentier monopoly profits by big tech companies (Standing, 2016) and the associated rising inequality (Boushey, Delong and Steinbaum, 2017; Piketty, 2020) remain strong. Jansson (2013) makes the case for an expansion of health, education, and care (HEC) services, in response to demographic change, a call that a UV economy could answer. One argument against UV planning in the past was the need for market price signals to direct resources efficiently, it may be that AI capabilities now overcome this information deficit and can help plan the UV aspect of GND implementation. Castells (2017) in Another Economy is Possible brings some of these economic ideas together. If, as economists propose, the post-virus economy is a turning point, in which way will it turn? The debate includes Streeck's (2017) six ways in which capitalism might end, and Castells' (2017) call for an anti-capitalist coalition.

\subsection{THEORY CONCLUSIONS}

In discussing post-virus PM, our article makes three contributions to the economics of PV in PM: (a) PV production/distribution does not have to be market mediated since UVs are inherently valuable as problem-solving wealth; (b) PV are created in a wider footprint than formal public services; and (c) PM research can benefit from widening its epistemic community to include economics in interdisciplinary research.

Like Moore (1995), we reject the idea that all valuable service outcomes are either best delivered by the market or judged against market efficiency standards. Our difference with Moore and subsequent PV theorists is around the extent to which UVs, without market value, are currently being produced and distributed without market mediation: UVs have what Inwin terms policy value. Migrating values to value (marketing literature in table 2) illustrates how the values of PV mediated via the market or produced by the formal public sector can embody the values of the public, how marketing literature underplays the UVs the public creates in households, the $3 \mathrm{~S}$ and community associations, not to mention the black economy. We argue that UVs are wealth that solves citizens' problems: $\mathrm{PV}=\mathrm{UV}=$ wealth. Figure 1 also summarises our response to co-creation research on PV: our argument that 
single-shot co-creation case studies while a valid research technique, may suffer from confirmation bias and neglects the much more significant stock and flow of value created as UVs. PVM too disregards the UVs produced by the public, focusing instead on the priorities and evaluations of the formal public sector.

We offer a new definition of PV and a new (wider) footprint of where and by whom it is created. We redefine PV to include UVs produced and distributed outside the formal public sector and unmediated by the market. These UVs fall into our definition of PV as wealth that solves a problem for citizens. We agree with Espeland and Stevens (1988), who argue that from the perspective of citizens, (though not the market or the formal public sector), UVs are inherently valuable: they solve problems. An incidental, not essential aspect of our contribution, argues that in the UK's case, UVs are now the dominant form of value production and distribution: an important argument in countering the neoliberal ideology of the predominance and pre-eminence of market relations.

Our third contribution acknowledges that PM though a hybrid discipline undertakes little interdisciplinary research involving macroeconomics. More frequent featuring of economics in the PM epistemic community is important since PM theory and policy constantly rubs against the economic environment. We make three points:

- PM cannot be neutral about economic policy. Moore's project was to challenge the neoliberal premise that only financial performance criteria are relevant. As Plehew, Slobodian and Mirowski (2020) show, left unchallenged neoliberalism reinvents itself; market fundamentalism is embedded in universities and international organisations. If PM requires an alternative economic policy, it must argue for it, following Connolly and Wall's (2016) argument that value cannot be reduced to financial computations.

- Economists too challenge neoliberal reductionism of all value to monetary value: Shackle (1972), Beinhocker (2007), Bronk (2009), Bookstabler (2017), and Tooze (2018) are examples. Challenging the claim that (neoliberal) economics is an incommensurably separated epistemic community from PM links with significant bodies of research favouring a quite different environment within which public services can operate and value be computed. Currently ideas from Baumol (2012) and others mythologise public services as non-productive and characterised by low productivity. PM has a responsibility to challenge these unwelcome incursions. The alternative is to vacate the field to neoliberals and passively accept that the economic environment is exogenously created by powers beyond the influence of PM theorists.

- Keynes' (1936) accusations against monetary economists included the fallacy of composition: aggregating firm-level logic to the whole economy. As Bozeman (2007) notes, PM too must be wary of concluding from single-shot case studies of co-creation that this is how an aggregated service might be run. General policy preferences, which may include full-employment and greater income equity will not be deduced from micro-level cases. Instead, 
they require the marriage between PM and economics this paper has promoted. The UV approach to PV views agency firmly at the point where citizens resolve their problem: deep levels of co-creation are not essential, nor is the Public Manager the central agent of production as Ostrom (1973) and Moore (2005) envisage.

\subsection{PRACTICE/POLICY}

Headline policies shown as desirable from our discussion include Jansson's (2013) expansion of HEC (health, education and care) services and employment; MMT's job guarantee for full-employment (Mitchell, 2020), Piketty's (2020) progressive taxes and the GND. Close examination of these policies reveals that only a sustained implementation period (say 10 years) would be necessary, radically altering not only economic policy but also the organisation, structure and mindset of public services. The danger is what Rosa Luxemburg criticised as a mini-max programme meaning minor change today, longer-term change so ambitious and ill-defined that it is never reached. For example, transition to MMT's policies (GND, Jobs and equity) requires a close working relationship between the Central Bank and Government Treasury, ending central bank independence and calling for new accountability arrangements. The jobs guarantee calls for locally planned and implemented expansion of health, education and care services, employment, and training: all major tasks.

PV creation using these policies and facilitating the UVs contributing to PV from our wider PV footprint are changes needing a lengthy period of stability and shared future vision, more often seen in the Asian development states than western market societies (perhaps with the Nordic exception). Success across election cycles can only be conceived if a clear and brave vision of social change captures society's trust: trust sufficiently deep to withstand trouble in the form of an unsupportive media. Pettit's (2017) notion of active republican citizenship becomes relevant in societies many of which are currently more inclined to populism and the passive citizenship resulting from deprivation and despair, instead of challenging the socially-destructive narrative of neoliberalism. We note also that neoliberal agents have successfully sidelined interventionist policies except those favouring profitable markets. Transition to MMT-type post-virus PV policies will be resisted and instead of being posited as an ideological alternative will perhaps be most successfully posited in terms of Dewey's (1939) pragmatic idealism, for example the social case for HEC jobs and services: redrawing the boundary of where UVs begin and EVs end. If a UV approach is chosen, for example technologically-assisted independent living with appropriate ambient services, a combined top-down and bottom-up planning and implementation may offer the line of least resistance. We stress, however, that market alternatives always exist such as (in this case) insurance-based private care with a minimalist state backup. Osborne's (2010) call for new governances and new service models is useful and perhaps especially attractive in the area of care where in some countries professionals have become more used to responding to austerity than to the challenges of HEC expansion. Continuing with the idea of radical new care models, already some local authorities are successfully 
deploying AI-based technologies to personalise care and offer ambient services, especially targeting, as Svendsen (2018) notes, the lonely-elderly, remembering that in Whiteside's (2011) hierarchies of care mental health can come low. We also note Brown's (2017) research on walled-welfare - the idea that high quality services for all can exacerbate tensions in relation to migrants.

As a contribution to debate, the article raises questions, without offering empirical support; it looks forward to arguments and the clarification of ideas, about the points where PV and PM and economics meet.

\section{Disclosure statement}

No potential conflict of interest was reported by the authors. 
1. Aglietta, M., 1979. A Theory of Capitalism Regulation. London: Verso.

2. Alford, J., 2011. Public Value from Coproduction by Clients. In: J. Benington and M. H. Moore. Public Value - Theory and Practice. Oxford: Oxford University Press, pp. 144-157.

3. Aligica, P. D. and Tarko, V., 2013. Polycentricity: From Polanyi to Ostrom, and Beyond. Governance, 25(2), pp. 237-262. https://doi.org/10.1111/j.14680491.2011.01550.x

4. Arthur, W. B., 2015. Complexity and the Economy. Oxford: Oxford University Press.

5. Atkinson, A. B. and Stiglitz, J., 2015. Lectures on Public Economics. Princeton University Press.

6. Auerswald, P., 2007. Creating social value. Stanford Social Innovation Review, 7(2), pp. 51-55.

7. Avent, R., 2017. The Wealth of Humans - Work and its Absence in the TwentyFirst Century. London: Penguin.

8. Barbrook, R., 2017. Imaginary Futures - from Thinking Machines to the Global Village. London: Pluto Press.

9. Bauman, Z., 2013. Does the Richness of the Few Benefit Us All? Cambridge: Polity Press.

10. Baumol, W., 2012. The Cost Disease. New Haven: Yale University Press.

11. Beer, S., 1979. The Heart of Enterprise. Chichester: John Wiley and Sons.

12. Beinhocker, E. D., 2007. The Origin of Wealth: Evolution, Complexity, and the Radical Remaking of Economics. London: Random House.

13. Benington, J. and Moore, M. H., 2011. Public Values in Complex and Changing Times. In: J. Benington and M. H. Moore. Public Value - Theory and Practice. Oxford: Oxford University Press, pp. 1-30.

14. Benington, J., 2009. Creating the public in order to create public value? International Journal of Public Administration, 32(3-4), pp. 232-249. https://doi. org/10.1080/01900690902749578

15. Benington, J., 2011. From private choice to public value. In: J. Benington and M. H. Moore. Public Value - Theory and Practice. Oxford: Oxford Uniersity Press, pp. 31-51.

16. Bergman, R., 2020. The Neoliberal era is ending: what comes next? The Correspondent, May 14, 2020.

17. Birchall, J., 2004. The mutualisation of public services in Britain: a critical commentary. Kurswechsel, (3), pp. 85-95.

18. Bookstaber, R., 2017. The End of Theory: Financial Crises, the Failure of Economics, and the Sweep of Human Interaction. New York: Princeton University Press.

19. Bourguignon, F., 2015. The Globalisation of Inequality. New York: Princeton University Press. 
20. Boushey, H., Delong, J. B. and Steinbaum, M. (eds.), 2017. After Piketty: The Agenda for Economics and Inequality. Cambridge, MA.: Harvard University Press. https://doi.org/10.4159/9780674978195

21. Boyer, R. and Shread, C., 2001. Regulation Theory: The State of the Art. London: Routledge.

22. Bozeman, B. and Johnson, J., 2014. The Political Economy of Public Values. A Case for the Public Sphere and Progressive Opportunity. The American Review of Public Administration, 45(1), pp. 61-85. https://doi.org/10.1177/ 0275074014532826

23. Bozeman, B. and Sarewitz, D., 2011. Public Value Mapping and Science Policy Evaluation. Minerva, 49(1), pp. 1-23. https://doi.org/10.1007/s11024-0119161-7

24. Bozeman, B., 2007. Public values and public interest: Counterbalancing economic individualism. Georgetown University Press.

25. Bridgeman, B. [et al.], 2012. Accounting for household production in the National Accounts, 1965-2010. Survey of Current Business, 92(5), pp. 23-36.

26. Brindle, J., 2018. New Dark Age - Technology and the End of the Future. London: Verso.

27. Bronk, R., 2009. The Romantic Economist - Imagination in Economics. Cambridge: Cambridge University Press.

28. Brown, W., 2017. Walled States, Waning Sovereignty. New York: Zone Books.

29. Bryson, J. M., Crosby, B. C. and Stone, M. M., 2014. The Design and Implementation of Cross-sector Collaborations: Propositions from the Literature. Public Administration Review, Special Issue, pp. 44-55. https://doi.org/10. 1111/j.1540-6210.2006.00665.x

30. Castells, M. [et al], 2017. Another Economy is Possible: Culture and Economy in a Time of Crisis. Cambridge: Polity.

31. Chang, H., 1994. The Political Economy of Industrial Policy. London: Macmillan.

32. Christophers, B., 2013. Banking across boundaries: Placing Finance in Capitalism. Sussex: Wiley-Blackwell. https://doi.org/10.1002/9781118295496

33. Christophers, B., 2018. The New Enclosure - The Appropriation of Public Land in Neoliberal Britain. London: Verso. https://doi.org/10.4000/metropoles.7715

34. CNBC, 2019. Modern Monetary Theory explained by Stephanie Kelton. CNBC, March 4, 2019.

35. Colon, M. and Guérin-Schneider, L., 2015. The reform of New Public Management and the creation of public values: compatible processes? An empirical analysis of public water utilities. International Review of Administrative Sciences, 81(2), pp. 264-281. https://doi.org/10.1177/0020852314568837

36. Connolly, C. and Wall, A., 2016. Value Capture: A Valid Means of Fund PPPs? Financial Accountability \& Management, 32(2), pp. 157-178. https://doi.org/ 10.1111/faam.12083

37. Coote, A. and Percy, A., 2020. The Case for Universal Basic Services. Cambridge: Polity. 
38. Cordella, A. and Bonina, C. M., 2012. A public value perspective for ICTenabled public sector reforms: A theoretical reflection. Government information quarterly, 29(4), pp. 512-520. https://doi.org/10.1016/j.giq.2012.03.004

39. Cordery, C. J. and Hay, D., 2019. Supreme Audit Institutions and public value: demonstrating relevance. Financial Accountability \& Management, 35(2), pp. 128-142. https://doi.org/10.1111/faam.12185

40. Cottrell, A. and Cockshott, W. P., 1993. Calculation, Complexity and Planning: The Socialist Calculation Debate Once Again. Review of Political Economy, 5(1), pp. 73-112. https://doi.org/10.1080/09538259300000005

41. Coyle, D., 2014. GDP: a brief but affectionate history. New York: Princeton University Press.

42. Crouch, C., 2011. Privates, Publics and Values. In: J. Benington and M. H. Moore. Public Value - Theory and Practice. Oxford: Oxford University Press, pp. 52-73.

43. Crouch, C., 2020. Post-Democracy After the Crises. Cambridge: Polity.

44. Delong, B., 2017. Grasping Reality by Brad DeLong.

45. Denhardt, R. B. and Denhardt, J. V., 2000. The New Public Service: Serving rather than steering. Public Administration Review, 60(6), pp. 549-559. https:// doi.org/10.1111/0033-3352.00117

46. Dewey, J., 1939. Freedom and Culture, Oxford: Oxford University Press.

47. Dietz, R. and O’Neill, D., 2013. Enough Is Enough: Building a Sustainable Economy in a World of Finite Resources. San Francisco: Berrett-Koehler Publishers.

48. Elson, D., 1979. Value: The Representation of Labour in Capitalism. London: CSE Books.

49. Epstein, G. A., 2019. What's Wrong with Modern Money Theory? A Policy Critique. New York: Palgrave-Macmillan.

50. Ermisch, J., 1990, Fewer Babies, Longer Lives. York: Joseph Rowntree Foundation.

51. Espeland, W. N. and Stevens, M. L., 1998. Commensuration as Social Process. Annual Review of Sociology, 24, pp. 313-343. https://doi.org/10.1146/ annurev.soc.24.1.313

52. Esping-Andersen, G. (ed.), 1990. The Three Worlds of Welfare Capitalism. London: Sage.

53. Eubanks, V., 2017. Automating Inequality: How High-Tech Tools Profile, Police and Punish the Poor. New York: St Martin's Press.

54. Federici, S., 2012. Revolution at Point Zero: Housework, reproduction and the Feminist Struggle. New York: PM Press.

55. Franklin, J., Graham, M. and Whittaker, M., 2016. Undervalued and overlooked? The need for better understanding civil society's contribution to the UK economy.

56. Gershuny, J. and Sullivan, O., 2019. What we really do all day. London: Pelican.

57. Gibson-Graham, J. K., 2006. The End of Capitalism (As We Know It): A Feminist Critique of Political Economy. Minneapolis: University of Minnesota Press. 
58. Giddens, A., 1991. Modernity and Self-Identity. Self and Society in the Late Modern Age. Cambridge: Polity.

59. Goldin, C. and Katz, L. F., 2008. The Race between Education and Technology. Cambridge: Harvard University Press.

60. Gooberman, L. and Hauptmeier, M., 2019. Employers' organisations and public value. In: M. H. Moore [et al.], eds. Public Value: Deepening, Enriching, and Broadening the Theory and Practice. London: Routledge, cpt. 16.

61. Grönroos, C. and Ojasalo, K., 2004. Service productivity: towards a conceptualisation of the transformation of inputs into economic results in services. Journal of Business Research, 57, pp. 414-423. https://doi.org/10.1016/s01482963(02)00275-8

62. Grönroos, C. and Voima, P., 2013. Critical service logic: Making sense of value creation and co-creation. Journal of the Academy of Marketing Science, 41(2), pp. 133-150. https://doi.org/10.1007/s11747-012-0308-3

63. Grönroos, C., 2007. In Search of a New Logic for Marketing. London: Wilery.

64. Haagh, L., 2019. The Case for Universal Basic Income. Cambridge: Polity.

65. Haldane, A., Brennan, S. and Madouros, V., 2010, The contribution of the financial sector: miracle or mirage. London: London School of Economics.

66. Hartley, J. [et al.], 2014. Public Value and Political Astuteness in the work of Public Managers: The art of the Possible. Public Administration, 93(1), pp. 195-211. https://doi.org/10.1111/padm.12125

67. Haskel, J. and Westlake, S., 2018. Capitalism without Capital: The Rise of the Intangible Economy. New York: Princeton University Press.

68. Hirsch, F., 1976. Social Limits to Growth. London: De Guyer.

69. Hochschild, A. R., 1983. The Managed Heart-commercialisation of human feeling. Berkeley: University of California Press.

70. Horner, L. and Hutton, W., 2011. Public Value, Deliberative Democracy, and the role of Public Managers. In: J. Benington and M. H. Moore. Public Value - Theory and Practice. Oxford: Oxford University Press, pp. 112-126.

71. Ilyambo, H. and Kaulihowa, T., 2020. An assessment of the relationship between public debt, government expenditure and revenue in Namibia. Public Sector Economics, 44(3), pp. 331-353. https://doi.org/10.3326/pse.44.3.3

72. Inwin, T. C., 2019. Not taking debt at face value, or market value or amortized cost: Policy value as a measure of the burden of public debt. Financial Accountability \& Management, 35(3), pp. 275-289. https://doi.org/10.1111/faam.12196

73. Ironmonger, D., 2004. Bringing up Bobby and Betty. In: N. Folbre and M. Bittman, eds. Family Time: The Social Organisation of Care. New York: Routledge, pp. 93-109.

74. Jackson, T., 2017. Prosperity without Growth. London: Routledge.

75. Janeway, W. H., 2018. Doing Capitalism in the Innovation Economy. Cambridge: Cambridge University Press.

76. Jansson, J. O., 2013. The Economics of Services - Micro-foundations, Development and Policy. Cheltenham: Edward Elgar. 
77. Johnson, C., 1982. MITI and the Japanese Miracle. Stanford: Stanford University Press.

78. Jorgenson, D. W., 2009. The Economics of Productivity. Northampton: Elgar Reference.

79. Jorgsen, T. and Bozeman, B., 2007. Public Value and Inventory. Administration and Society, 39(3), pp. 354-381.

80. Kahneman, D. and Tversky, A., 1979. Prospect theory: An analysis of decision under risk. Econometrica: Journal of the Econometric Society, 47(2), pp. 263291. https://doi.org/10.2307/1914185

81. Kallis, G., 2018. Degrowth. Newcastle: Agenda Publishing.

82. Kantorovich, L. V., 1939. Mathematical Models of Organising and Planning Production. Management Science, 6, pp. 363-422.

83. Kelly, G., Mulgan, G. and Muers, S., 2002. Creating Public Value: An Analytical Framework for Public Service Reform. Discussion paper prepared by the Cabinet Office Strategy Unit, United Kingdom.

84. Kelton, S., 2020. The Deficit Myth - Modern Monetary Theory and How to Build a Better Economy. London: John Murray.

85. Keynes, J. M., 1936. The General Theory of Employment, Interest and Money. In: The Collected Writings of John Maynard Keynes, vol. 7. London: St. Martin Press. https://doi.org/10.1017/upo9781139524278.019

86. Kinder, T. [et al.], 2020. The dark side of artificial intelligence in local public services: a foresighting perspective. Tampere University Working Paper.

87. Kinder, T., 2003. Supply relations in the era of the extended enterprise model: a conceptual framework for value stream benchmarking. Research Policy, 32(3), pp. 503-523. https://doi.org/10.1016/s0048-7333(02)00021-5

88. Kinder, T., 2012. Learning, Innovation and Performance in Post-New Public Management of Locally Delivered Public Services. Public Management Review, 14(3), pp. 403-428. https://doi.org/10.1080/14719037.2011.637408

89. Klein, N., 2019. On Fire - The Burning Case for a Green New Deal. London: Penguin.

90. Knox, K. and Worpole, K., 2007. The social value of public spaces. New York: Joseph Rowntree Foundation.

91. Kolbert, E., 2011. The Sixth Extinction - An Unnatural History. London: Bloomsbury.

92. Kotler, P., 1984. Marketing management: Analysis, Planning and Control. New York: Prentice Hall.

93. Krugman, P., 2020a. Arguing with Zombies: Economics, Politics and the Fight for a Better Future. New York: Norton \& Co.

94. Krugman, P., 2020b. Paul Krugman on Modern Monetary Theory.

95. Kuoppakangas, P. [et al.], 2019. Examining the Core Dilemmas Hindering Big Data-related Transformations in Public-Sector Organisations. Journal of Public Administration and Police, 12(2), pp. 131-156. https://doi.org/10.2478/ nispa-2019-0017 
96. Kurz, R., 2019. Post-growth perspectives: Sustainable development based on efficiency and sufficiency. Public Sector Economics, 43(4), pp. 401-422. https://doi.org/10.3326/pse.43.4.4

97. Kuznets, S., 1946. National Product Since 1869. New York: National Bureau of Economic Research.

98. Laitinen, I., Stenvall, J. and Kinder, T., 2017. Co-design and action learning in local public services. Journal of Adult \& Continuing Education, 24(1), pp. 58-80. https://doi.org/10.1177/1477971417725344

99. Lazonick, W. and Shin, J.-S., 2020. Predatory Value Extraction: How the Looting of the Business Corporation became the US norm and How Sustainable Prosperity Can be Restored. Oxford: Oxford University Press. https:// doi.org/10.1093/oso/9780198846772.001.0001

100. Leibenstein, H., 1966. Allocative efficiency and X-efficiency. Oxford: Oxford University Press.

101. Lewin, A. Y., Kenney, M. and Murmann, J. P. (eds.), 2016. China's Innovation Challenge - Overcoming the Middle-Income Trap. Cambridge: Cambridge University Press.

102. Lindgreen, A. [et al.], 2019. Public Value: Deepening, Enriching, and Broadening the Theory and Practice. London: Routledge. https://doi.org/10.4324/ 9781315163437

103. Luxemburg, R., 1969. The Rosa Luxemburg Reader. London: Pluto Press.

104. Marx, K., 1973. Grundrisse. Middlesex: Penguin.

105. Mayer, J., 2016. Dark Money - How a Secretive Group of Billionaires is Trying to Buy Political Control in the US. London: Scribe.

106. Mazzucato, M., 2013. The Entrepreneurial State: debunking public vs private sector myths. London: Anthem Press.

107. Mazzucato, M., 2018. The Value of Everything - Making and Taking in the Global Economy. London: Allen Lane.

108. McAfee, A. and Brynjolfsson, E., 2017. Machine, Platform, Crowd: Harnessing Our Digital Future. New York: W. W. Norton \& Company.

109. Medina, E., 2011. Cybernetic Revolutionaries: Technology and Politics in Allende's Chile. Cambridge: MIT Press. https://doi.org/10.7551/mitpress/ 8417.001 .0001

110. Meynhardt, T., 2009. Public value inside: What is public value creation? International Journal of Public Administration, 32(3-4), pp. 192-219. https://doi. org/10.1080/01900690902732632

111. Meynhardt, T., 2019. Public value: value creation in the eyes of society. In: M. H. Moore [et al.], eds. Public Value: Deepening, Enriching, and Broadening the Theory and Practice. London: Routledge, pp. 5-39.

112. Milanovic, B., 2016. Global Inequality: A new approach for the Age of Globalisation. Harvard: Harvard University Press.

113. Mitchell, B., 2020a. Modern Monetary Theory: Macroeconomic research, teaching and advocacy. 
114. Mitchell, R. C. and Carson, R. T., 1989. Using survey to value public goods: the contingent valuation method. Washington: Routlege.

115. Mitchell, W. F. and Fazi, I., 2017. Reclaiming the State: A Progressive Vision of Sovereignty for a Post Neoliberal World. London: Pluto Books. https://doi. org/10.2307/j.ctt1v2xvvp

116. Monbiot, G., 2015. Bring on the Apocalypse: Six Arguments for Global Justice. London: Guardian Books.

117. Moore, M. H. and Khargram, S., 2004. On creating public value: What Business might learn from Government about Strategic Management. Corporate Social Imitative Working Paper, No. 3.

118. Moore, M. H., 1995. Creating public value: Strategic management in government. Harvard: Harvard University Press.

119. Moore, M., 2005. Creating public value through private/public partnerships. $X$ Congreso Internacional del CLAD sobre la Reforma del Estado y de la Administracion Publica, Santiago, Chile (18-21 October).

120. Mulgan, G., 2007. Good and bad power: the ideals and betrayals of government. London: Penguin.

121. NCVO, 2020. What is the economic contribution of the voluntary sector? London: NCVO.

122. Normann, R., 2002. Service Management. New York: John Wiley \& Sons.

123. O’Neil, K., 2016. Weapons of Math Destruction: How Big Data Increases Inequalities and Threatens Democracy. London: Penguin.

124. Omurgonulsen, U. and Oktem, M. K., 2009. Is There Any Change in the Public Service Values of Different Generations of Public Administrators? The Case of Turkish Governors and District Governors. Journal of Business Ethics, 88, pp. https://doi.org/10.1007/s10551-009-0111-3

125. ONS, 2021a. Gross Domestic Product (GDP). London: Office for National Statistics.

126. ONS, 2021b. Public Sector Finance. London: Office for National Statistics.

127. Osborne, S. P. and Brown, K., 2005. Managing change and innovation in public services organisations. London: Routledge.

128. Osborne, S. P., 2010. The (New) Public Governance: a suitable case for treatment. In: S. P. Osborne. The New Public Governance? London: Routledge.

129. Osborne, S. P., 2020. Public Service Logic. London: Routledge.

130. Osborne, S. P., 2017. From public service-dominant logic to public service logic: are public service organisations capable of coproduction and value cocreation? Public Management Review, 20(2), pp. 225-231. https://doi.org/10.1080/14719 037.2017.1350461

131. Ostrom, E., 1990. Governing the Commons: The Evolution of Institutions for Collective Action. Cambridge: Cambridge University Press.

132. Ostrom, E., 1996. Crossing the great divide: coproduction, synergy, and development. World development, 24(6). pp. 1073-1087. https://doi.org/10. 1016/0305-750x(96)00023-x 
133. Paul, M., Darity, W. and Hamilton, D., 2018. The Federal Job Guarantee. Washington: Centre on Budget and Policy Priorities.

134. Pettit, P., 1997. Republicanism: A Theory of Freedom and Government. Oxford: Clarendon Press.

135. Piketty, T., 2013. Capital in the Twenty-first Century. Cambridge: Harvard University Press.

136. Piketty, T., 2020. Capital and Ideology. Cambridge: Harvard University Press.

137. Pisano, G., 2011. Science Business. Brighton: Harvard Business School Press.

138. Plehew, D., Slobodian, Q. and Mirowski, P. (eds.), 2020. Nine Lives of Neoliberalism. New York: Verso.

139. Polanyi, K., 2001. The Great Transformation - The Political and Economic Origins of Our Time. Massachusetts: Beacon Press.

140. Raey, M., 2009. Impacts and implications of climate change. Berlin: Springer.

141. Rhodes, R. A. W. and Wanna, J., 2007. The Limits to Public Value, or Rescuing Responsible Government from the Platonic Guardians. Australian Journal of Public Administation, 66(4), pp. 406-421. https://doi.org/10.1111/ j.1467-8500.2007.00553.x

142. Ricketts, A., 2020. Economic worth of the sector 'chronically undervalued', report concludes. Third Sector, May 20, 2020.

143. Roberts, A., 1995. Civic Discovery as Rhetorical Strategy. Journal of Policy Analysis and Management, 14(2), pp. 291-307.

144. Rutger, C., 2020. Capabilities in a Just Soceity. Oxford: Oxford University Press.

145. Rutgers, M. R., 2008. Sorting Out Public Values? On the Contingency of Value Classification in Public Administration. Administrative Theory and Praxis, 30(1). https://doi.org/10.1080/10841806.2008.11029617

146. Sandel, M. J., 2009. Justice - What's the Right Thing to Do? London: Allen Lane.

147. Scheidel, W., 2017. The Great Leveller: violence and the history of inequality from the Stone Age to the Twenty-First Century. Princeton: Princeton University Press.

148. Schumaker, E. F., 1985. Small is Beautiful: A Study of Economics as if People Mattered. London: Vintage Books.

149. Sen, A., 1985. Commodities and capabilities. New York: North Holland.

150. Sen, A., 1999. Commodities and Capabilities. Oxford: Oxford University Press.

151. Shackle, G. L. S., 1972. Epistemics and Economics - A Critique of economic doctrines. Cambridge: Cambridge University Press.

152. Shaxson, N., 2016. Treasure Islands: Tax Havens and the Men Who Stole the World. New York: Vintage.

153. Sheikh, S. and Yousafzai, S., 2019. Public value creation through the lens of women's entrepreneurship. In: M. H. Moore [et al.], eds. Public Value: 
Deepening, Enriching, and Broadening the Theory and Practice. London: Routledge, cpt. 17.

154. Slobodian, Q., 2018. Globalists - The End of Empire and the Birth of Neoliberalism. Cambridge: Harvard University Press. https://doi.org/10.1017/ s1537592718002219

155. St. Francis College, 2018. L. Randall Wray - Modern Money Theory for Beginners. Youtube, April 25, 2018.

156. Standing, G., 2016. The Corruption of Capitalism - Why Rentiers Thrive and Work Does Not Pay. London: Biteback Publishing.

157. Statista, 2021. Total public sector current expenditure as a share of gross domestic product (GDP) in the United Kingdom (UK) from 1977/78 to 2019/20.

158. Stern, N., 2006. Stern Report on Economics of Climate Change. London: HM Treasury.

159. Stoker, G., 2006. Public value management: A new narrative for networked governance? The American Review of Public Administration, 36(1), pp. 41-57. https://doi.org/10.1177/0275074005282583

160. Streeck, W, 2017. How Will Capitalism End. London: Verso.

161. Streeck, W., 1992. Social Institutions and Economic Performance. London: Sage.

162. Suh, J. and Payne, C., 2019. Unpaid Work Matters - Valuing Unpaid Household Production Time. In: J. Gershuny and O. Sullivan. What We Really Do All Day: Insights from the Centre for Time Use Research. New York: Penguin Books.

163. Suh, Y. and Folbre, N., 2016. Valuing Unpaid Child Care in the US. Review of Income and Wealth, 62(4), pp. 668-684. https://doi.org/10.1111/roiw.12193

164. Svendsen, L., 2018. A Philosophy of Loneliness. London: Reaktion Books.

165. Tcherneva, P. R., 2012. Beyond full-employment: The Employer of Last Resort as an Institution for Change. Levy Economics Institute of Bard College Working Paper, No. 732. https://doi.org/10.2139/ssrn.2153220

166. Thompson, E. P., 1967. The Making of the English Working Class. Harmondsworth: Pelican.

167. Thunberg, G., 2019. No One is Too Small to Make a Difference. London: Penguin.

168. Tirronen, A. [et al.], 2020. How to Measure Wellbeing in Outcomes-based Commissioning? Lex Localis, 18(1), pp. 123-142. https://doi.org/10.4335/ 18.1.123-142(2020)

169. Tooze, A., 2018. Crashed - How a Decade of Financial Crises Changed the World. London: Allen Lane.

170. Try, D. and Radnor, Z., 2007. Developing an understanding of results-based management through public value theory. International Journal of Public Sector Management, 20(7), pp. 655-673. https://doi.org/10.1108/09513550 710823542

171. Van Parijs, P. and Vanderborght, Y., 2020. Basic Income: A Radical Proposal for a Free Society and a Sane Economy. Cambridge: Harvard University Press. https://doi.org/10.4159/9780674978072 
172. Vargo, S. L. and Lusch, R. F., 2008. Service-Dominant Logic: Continuing the evolution. Journal of Academic Marketing, 36, pp. 1-10.

173. Vargo, S. L., Maglio, P. P. and Akaka, M. A., 2008. On value and value cocreation: a service systems and service logic perspective. European Management Journal, 26(3), pp. 145-152. https://doi.org/10.1016/j.emj.2008.04.003

174. Wahhab, I., 2016. Charity Sucks. London: Biteback.

175. Warde, A., 1994. Consumers, identity and belonging. In: S. Schwarzkopf. The Authority of the Consumer. London: Routledge.

176. Wensley, R. and Moor, M. H., 2011. Choice and Marketing in Public Management: The Creation of Public Value. In: J. Benington and M. H. Moore. Public Value - Theory and Practice. Oxford: Oxford University Press, pp. 127-143.

177. Westall, A., 2009. Value and the third sector. Third Sector Research Centre, Working Paper, No. 25.

178. Whiteside, N., 2011. Creating Public Value: The Theory of the Convention. In: J. Benington and M. H. Moore. Public Value - Theory and Practice. Oxford: Oxford University Press, pp. 74-89.

179. Wikipedia, 2021. Commission on the Measurement of Economic Performance and Social Progress.

180. Wincer, P., 2020. Tender: The Imperfect Art of Caring. London: Coronet.

181. Winters, J. A., 2011. Oligarchy. Cambridge: Cambridge University Press.

182. Wolf, A., 2017. The XX Factor: How the Rise of Working Women Has Created a Far Less Equal World. New York: Skyhorse.

183. Woo-Cumings, M. (ed), 1999. The developmental state. London: Cornell University Press.

184. Zucman, G., 2015. The Hidden Wealth of Nations: The Scourge of Tax Havens. Chicago: The University of Chicago Press. https://doi.org/10.7208/ chicago/9780226245560.001.0001 